\title{
Cell penetrating peptide-modified nanoparticles for tumor targeted imaging and synergistic effect of sonodynamic/HIFU therapy [Corrigendum]
}

\author{
Li Y, Hao L, Liu F, et al. Int $J$ Nanomedicine. \\ 2019; 14:5875-5894.
}

The authors have advised that affiliation 1 for this paper was presented incorrectly as it was split into two affiliations and this was not corrected before the paper was published.

They have advised that the correct author and affiliation list is:

Yizhen $\mathrm{Li}^{1,2, *}$ Lan Hao, ${ }^{1, *}$ Fengqiu Liu, ${ }^{1}$ Lixue Yin, ${ }^{2}$ Sijing Yan, ${ }^{3}$ Hongyun Zhao, ${ }^{1,4}$ Xiaoya Ding, 5 Yuan Guo, ${ }^{1}$ Yang Cao, ${ }^{1}$ Pan Li, ${ }^{1}$ Zhigang Wang, ${ }^{1}$ Haitao Ran, ${ }^{1}$ Yang Sun $^{1}$
${ }^{1}$ Second Affiliated Hospital of Chongqing Medical University \& Chongqing Key Laboratory of Ultrasound Molecular Imaging, Chongqing 400010, People's Republic of China; ${ }^{2}$ Department of Cardiovascular Ultrasound and Noninvasive Cardiology, Sichuan Academy of Medical Science \& Sichuan Provincial People's Hospital, Chengdu, Sichuan Province 610072, People's Republic of China; ${ }^{3}$ Chongqing Hospital of Traditional Chinese Medicine, Chongqing 400021, People's Republic of China; ${ }^{4}$ Department of Gastroenterology, The Second Hospital Affiliated to Chongqing Medical University, Chongqing 400010, People's Republic of China; ${ }^{5}$ Department of Ultrasound, University-Town Hospital of Chongqing Medical University, Chongqing 401331, People's Republic of China

*These authors contributed equally to this work

\section{Publish your work in this journal}

The International Journal of Nanomedicine is an international, peerreviewed journal focusing on the application of nanotechnology in diagnostics, therapeutics, and drug delivery systems throughout the biomedical field. This journal is indexed on PubMed Central, MedLine, CAS, SciSearch ${ }^{\mathbb{B}}$, Current Contents ${ }^{\mathbb{B}} /$ Clinical Medicine,

Journal Citation Reports/Science Edition, EMBase, Scopus and the Elsevier Bibliographic databases. The manuscript management system is completely online and includes a very quick and fair peer-review system, which is all easy to use. Visit http://www.dovepress.com/ testimonials.php to read real quotes from published authors. 